\title{
Comfort and tolerability of protective face masks used by healthcare professionals during the COVID-19 pandemic
}

\author{
COVID-19 Salgını Sırasında Sağlık Profesyonelleri Tarafından Kullanılan Koruyucu Yüz Maskelerinin \\ Rahatlığı ve Tolere Edilebilirliğinin Değerlendirilmesi
}

Murat Duyan ${ }^{1}$, Ibrahim Ulas Ozturan ${ }^{2}$, Mustafa Ayhan Ozbek ${ }^{3}$, Hüseyin Sevil ${ }^{4}$, Okkes Zortuk ${ }^{1}$, Resmiye Nur Okudan Kildan ${ }^{5}$, Fatih Selvi ${ }^{1}$, Aslıhan Yuruktumen Unal ${ }^{3}$, Yıldıray Cete $^{3}$

${ }^{1}$ Department of Emergency Medicine, Antalya Training and Research Hospital, Antalya, Turkey

${ }^{2}$ Department of Emergency Medicine, Kocaeli University, Faculty of Medicine, Kocaeli, Turkey

${ }^{3}$ Department of Emergency Medicine, Akdeniz University, Faculty of Medicine, Antalya, Turkey

${ }^{4}$ Department of Emergency Medicine, Uşak Training and Research Hospital, Uşak, Turkey

${ }^{5}$ Department of Emergency Medicine, Gebze Fatih State Hospital, Kocaeli, Turkey

\section{ABSTRACT}

Introduction: The severe acute respiratory syndrome coronavirus 2 (SARS-CoV-2) virus is transmitted by respiratory droplets, and all healthcare professionals (HCPs) have been required to use protective face masks during long working hours. However, the tolerability of different types of face masks varies and can lead to physical or psychological burden for wearer. This study aimed to determine the tolerability and symptoms of commonly used face masks among HCPs.

Methods: This prospective observational study was conducted in the COVID-19 areas of three academic emergency departments (EDs). HCPs, including physicians, nurses, and other personnel were included. The comfort and tolerability of surgical masks, filtering face piece-2 (FFP2), and FFP3 respirators and the symptoms experienced during the four-hour study period were evaluated hourly. The primary outcomes were the severity and duration of discomfort or symptoms experienced according to the type of mask used.

Results: A total of 181 volunteer HCPs were included in the study. Dyspnea was the most common symptom. According to a seven-point Likert scale that measured the wearer's experience of symptoms, the severity of the first discomfort/symptom was two points on average, and the main discomfort/symptom that led to masking removal was four points. The median time for the appearance of discomfort/symptoms was 70 minutes for the single-layer surgical masks and 50 minutes for the FFP2 and FFP3 masks.

Conclusion: Dyspnea and headache were the most common causes of intolerance to masks used by HCPs. Although statistical significance was not achieved, the duration of mask use was lower in those who used FFP2 and FFP3 masks.

Keywords: Occupational Health, Personal protective equipment, COVID-19, Face mask, Respiratory Protection/Respirators

\section{ÖZET}

Giriş: Şiddetli akut solunum sendromu koronavirüs 2 (SARS-CoV2) virüsü solunum damlacıkları ile bulaşır ve tüm sağlık çalışanlarının uzun çalışma saatleri boyunca koruyucu yüz maskeleri kullanmaları istenmiştir. Bununla birlikte, farklı yüz maskelerinin tolere edilebilirliği değişiklik gösterir ve kullanıcı için fiziksel veya psikolojik yüke yol açabilir. Bu çalışma, sağlık çalışanları arasında yaygın olarak kullanılan yüz maskelerinin tolere edilebilirliğini ve semptomlarını belirlemeyi amaçlamıştır.

Yöntemler: Bu prospektif gözlemsel çalışma, üç akademik acil servisin (ED) COVID-19 alanlarında yürütülmüştür. Doktorlar, hemşireler ve diğer personel dahil olmak üzere tüm sağlık çalışanları dahil edildi. Cerrahi maskeler, FFP2 ve FFP3 solunum cihazlarının konforu ve tolere edilebilirliği ile dört saatlik çalışma süresi boyunca yaşanan semptomlar saatlik olarak değerlendirildi. Birincil sonuçlar, kullanılan maske tipine göre yaşanan rahatsızlık veya semptomların şiddeti ve süresiydi.

Bulgular: Çalışmaya toplam 181 gönüllü sağlık çalışanı dahil edildi. Dispne en sık görülen semptomdu. Kullanıcının semptom deneyimini ölçen yedi puanlık bir Likert ölçeğine göre, ilk rahatsızığın/semptomun şiddeti ortalama iki puan ve maskenin çıkarılmasına yol açan ana rahatsızlık/semptomun dört puan olduğu görüldü. Rahatsızlık/semptomların ortaya çıkması için medyan süre, tek katmanlı cerrahi maskeler için 70 dakika ve FFP2 ve FFP3 maskeleri için 50 dakika idi.

Sonuç: Dispne ve baş ağrısı, sağlık çalışanları tarafından kullanılan maskelere karşı en yaygın intoleransın nedenleriydi. İstatistiksel anlamlılık elde edilemese de FFP2 ve FFP3 maske kullananlarda maske kullanım süresi daha düşüktü.

Anahtar Kelimeler: İş Sağlığı, Kişisel koruyucu donanım, COVID-19, Yüz maskesi, Solunum Koruması/Solunum Cihazları

\section{Corresponding author: Murat Duyan, Department of Emergency Medicine, Antalya Training and Research Hospital, Antalya, Turkey \\ E-mail: drmuratduyan@gmail.com \\ Eskisehir Med. J. 2022; 3(1):17-26.}

Received date:28.10.2021 Accepted date:28.01.2022

Authors: Murat Duyan (ORCID: 0000-0002-6420-3259), Ibrahim Ulas Ozturan (ORCID: 0000-0002-1364-5292), Mustafa Ayhan Ozbek (ORCID: 00000002-5107-753X), Hüseyin Sevil (ORCID: 0000-0002-2618-8318), Okkes Zortuk (ORCID: 0000-0001-6776-2702), Resmiye Nur Okudan Kildan

(ORCID: 0000-0003-4187-7928), Fatih Selvi (ORCID: 0000-0002-9701-9714), Aslihan Yuruktumen Unal (ORCID: 0000-0002-6386-2148), Yildiray Cete 


\section{INTRODUCTION}

The severe acute respiratory syndrome coronavirus 2 (SARS-CoV-2) virus, which is responsible for the COVID-19 pandemic, has resulted in 4,777,272 deaths worldwide $(1,2)$. During the COVID-19 pandemic, the workload of healthcare professionals (HCPs) who struggle on the front line with COVID-19 has dramatically increased (3). The infection affects HCPs who are exposed to significant viral loads more frequently than the general population (4). The most important responsibility of healthcare administrators is to take the necessary protective measures within the scope of occupational health and safety for employed workers.

The use of surgical masks, filtering face mask respirators, such as N95, N99, and other personal protective equipment (PPE) by HCPs who undertake the follow-up and treatment of infected patients is recommended by the World Health Organization (WHO) to prevent contamination (5). Recommended PPE also includes aprons, gloves, and face shields. Although the United States (US) and the European Union standards have different definitions, N95 and N99 respirators are accepted as equivalent to filtering face piece-2 (FFP2) and FFP3 respirators, respectively, based on safety and efficacy $(6,7)$.

Tight-fitting masks can cause poor ventilation, and higher levels of carbon dioxide $\left(\mathrm{CO}_{2}\right)$ result in clinical hypercapnia (8). Since $\mathrm{CO}_{2}$ is a known respiratory stimulant, the accumulation of exhaled $\mathrm{CO}_{2}$ between the mask and the face causes an increase in lung ventilation and respiratory activity. Symptoms of hypoxia, such as chest discomfort and tachypnea, may also occur in HCPs who wear masks for a long time. High $\mathrm{CO}_{2}$ levels can also cause confusion, cognitive impairment, and disorientation (8). However, $\mathrm{CO}_{2}$ accumulation is not expected in valved masks where air comes out of the valve when exhaled (9).
Although the protective mechanisms of respirators are mostly physical and sometimes chemical, they impose a range of physiological and psychological burdens (10). These factors may affect HCPs' work performance and reduce their work capacity. The warm and humid environment in hospital settings, where the face is covered with a mask, can cause a particular level of discomfort and hyperthermia(11). This can create a situation where HCPs are unable to recognize hazards or perform critical tasks, and their motor skills may be significantly affected as well (10). However, little is known about the workplace tolerability of respirators commonly worn by HCPs during long work shifts (12).

Various symptoms of long-term mask use have been reported for HCPs who are working on the front line with patients infected with COVID-19 (13). This study aimed to investigate the potential symptoms of different types of masks used in the early period of the pandemic and to determine the most effective working time for healthcare workers.

\section{METHODS}

\section{Study design and settings}

This multicenter prospective cross-sectional study was conducted in the COVID-19 areas of three academic emergency departments (EDs) between January 2021 and March 2021. Institutional review board approval (Antalya Training and Research Hospital Ethical Committee, Number: 16/14; Date: November 22, 2020) and the informed consent of the volunteers were obtained for the study.

This study included volunteer doctors, nurses, and other HCPs who had an active role in patient care in the COVID-19 areas of hospital EDs. Participants were eligible if they did not have remarkable health problems (for example hypertension, chronic obstructive pulmonary diseases, asthma and other chronic illness), who used PPE in line with the WHO recommendations, and who had no history of COVID-19 infection. 
Pregnant women and those with a history of panic disorder or claustrophobia were excluded from the study.

\section{Study protocol}

All the HCPs working in the COVID-19 care in the ED were approached for the study before the 4 hours long shift began. The volunteers who agreed to participate in the study were given information about the study design. A preliminary systemic physical examination was conducted to exclude acute health problems. All participants' medical history and used medication were noted. We confirmed that the volunteers wore the masks that they preferred appropriately and that they did not have any acute symptoms or complaints at the beginning of the study. The volunteers in each ED had a choice of mask between surgical, FFP2, and FFP3 masks. The average temperature of the working environment was $24-28 C^{\circ}$ (75.2-82.4 Fahrenheit). The moment the volunteers donned their mask, which they would wear continuously for four hours or until they removed it due to symptoms or discomfort while caring for patients with COVID-19 in the ED, was the study's starting point. The volunteers' demographic data (sex, age, and profession), smoking history, alcohol use, body mass index (BMI), comorbidities, preferred mask type, and use of additional PPE other than masks were recorded.

After starting patient care, the onset of the volunteers' symptoms/discomfort due to mask use was recorded by observer doctor. The severity of symptoms/discomfort was determined using a Likert scale $(1=$ no symptoms to 7 = most severe symptoms). The volunteers were followed up for a maximum of four hours, which was the end time for the study, and systematically questioned about their symptoms on the hour for four hours. In the cases of the volunteers who removed the mask before four hours, the main symptoms and/or reasons leading to mask removal were recorded.

\section{Outcome measures}

The primary outcome of this study was the severity and duration of symptoms/discomfort (Shortness of breath, Chest pain , Headache, Dizziness , Nausea/vomiting, Blurred vision, Palpitation, Tachypnea, A feeling of fainting, Increased Anxiety )for all mask types and according to the type of mask used. The secondary outcomes were the main symptoms causing mask removal before four hours and the optimum effective working duration for each mask type.

\section{Data analysis}

IBM SPSS Statistics 18 (SPSS Inc. Chicago, IL, USA) was used to analyze the data. The conformity of the continuous variables to normal distribution was examined using the Kolmogorov-Smirnov test. The categorical variables were presented as frequency $(n)$ and percentage (\%), and the continuous variables were presented as means \pm standard deviations (SD) or medians and interquartile ranges according to the normality of distribution. The Chi-square test and the Fisher-Freeman-Halton exact test were used in the analysis of the categorical variables, and the Bonferroni correction was made. When parametric test assumptions were not met, the Mann-Whitney $U$ test was used to compare two groups' means, and the Kruskal-Wallis test and post hoc pairwise comparison tests were used to compare more than two groups. The statistical significance level was accepted as $p<0.05$ in the study.

\section{RESULTS}

Of the 181 participants in the study, $102(56 \%)$ were male. The volunteers using FFP2 masks used additional PPE significantly more often than the participants using other types of masks $(p<0.001)$. The total mask-wearing duration was lower in those using FFP2 and FFP3 masks, but this difference was not statistically significant $(p=0.082)$. In the analysis 
according to occupation, nurses' use of surgical masks was significantly lower than their use of FFP2 masks (Fig. 1). The participants' sociodemographic characteristics are shown in Table 1.

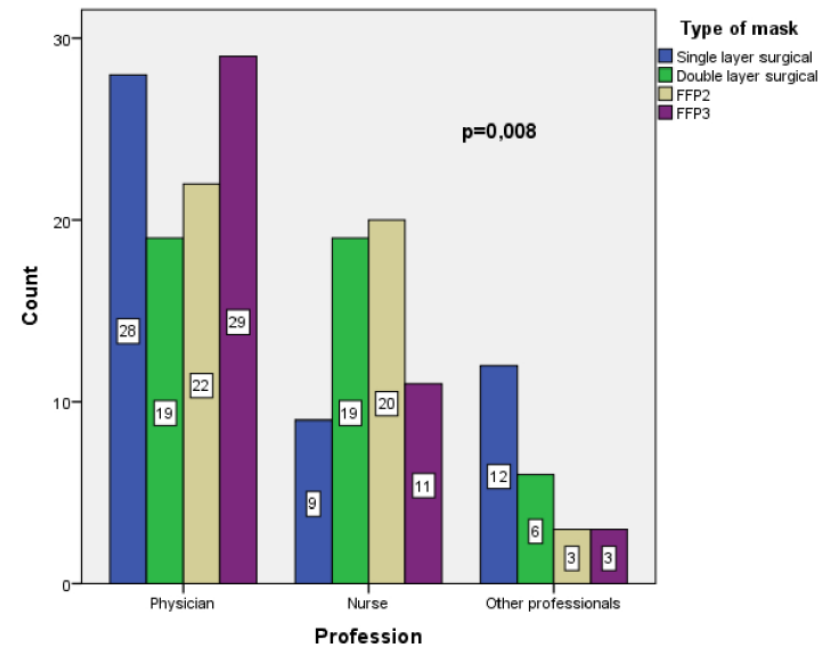

Figure 1. Preffered mask type according to occupations.

The characteristics of the symptoms according to the type of mask used are presented in Table 2. The most common first symptom for all mask types was dyspnea (86.2\%). In addition, headache (7.7\%), increased anxiety $(2.8 \%)$, chest pain (1.7\%), and dizziness (0.6\%) were observed. The severity of the first symptom/discomfort had a median of 2 (minimum $1=$ no symptoms/discomfort to maximum $7=$ most severe symptoms/discomfort) for all mask types according to the 7-point Likert scale. The time for the first symptom/discomfort to appear was a median of 70 minutes for the single-layer surgical masks and 50 minutes for the double-layer surgical, FFP2, and FFP3 masks; however, this was not statistically significant ( $p$ $>0.05$ ). The most common symptoms that led to mask removal were dyspnea (34.8\%) and chest pain (33.7\%). The main symptom was defined as the symptom that caused the wearer to remove the mask. The severity of the main symptoms in all mask types was a median of 4 (minimum 1 = no symptoms to maximum $7=$ most severe symptoms), according to the 7-point Likert scale. In the group that removed their masks before four hours, the median duration of the symptoms was $20(10-30)$ minutes for the single-layer surgical masks and the FFP3 masks and 15 minutes (5-30) for the double-layer surgical masks and the FFP2 masks ( $p>$ $0.05)$. A total of seven volunteers required medical treatment due to headache, which was the main symptom causing mask removal; of these seven, three were in the group using double-layer surgical masks, two were using single-layer surgical masks, and one each was in the FFP2 and the FFP3 groups.

The presence of symptoms related to mask use did not differ according to sex, age, smoking history, alcohol use, use of other PPE, BMI, occupation, and comorbidities ( $p>0.05$ ) (Table 3 ).

The findings are presented in Table 4. Dyspnea at the first and second hours was significantly lower in those using surgical masks compared to those using FFP2 and FFP3 masks $(p<0.001)$. Headache in the first hour was not seen at all in those using surgical masks; it was most common in those using FFP2 masks (15.6\%) $(p=$ 0.018 ). At the second hour, headache increased for all mask types, but it was significantly lower in surgical mask users $(p=0.011)$. In the first analysis, dizziness at the second hour and nausea/vomiting at the third hour were significantly higher in the volunteers who used double-layer surgical masks $(p=0.047, p=$ 0.039 , respectively), but this difference did not appear in further analysis $(p>0.05)$. Tachypnea at the second hour was significantly higher in the FFP2 mask users than in the surgical mask users $(p<0.001)$. Increase in anxiety at the first hour was found to be different between mask types, as it was not seen in the surgical mask users $(p=0.032)$. The difference at the second hour did not appear in further analysis. 
Table 1. Type of mask used according to sociodemographic characteristics

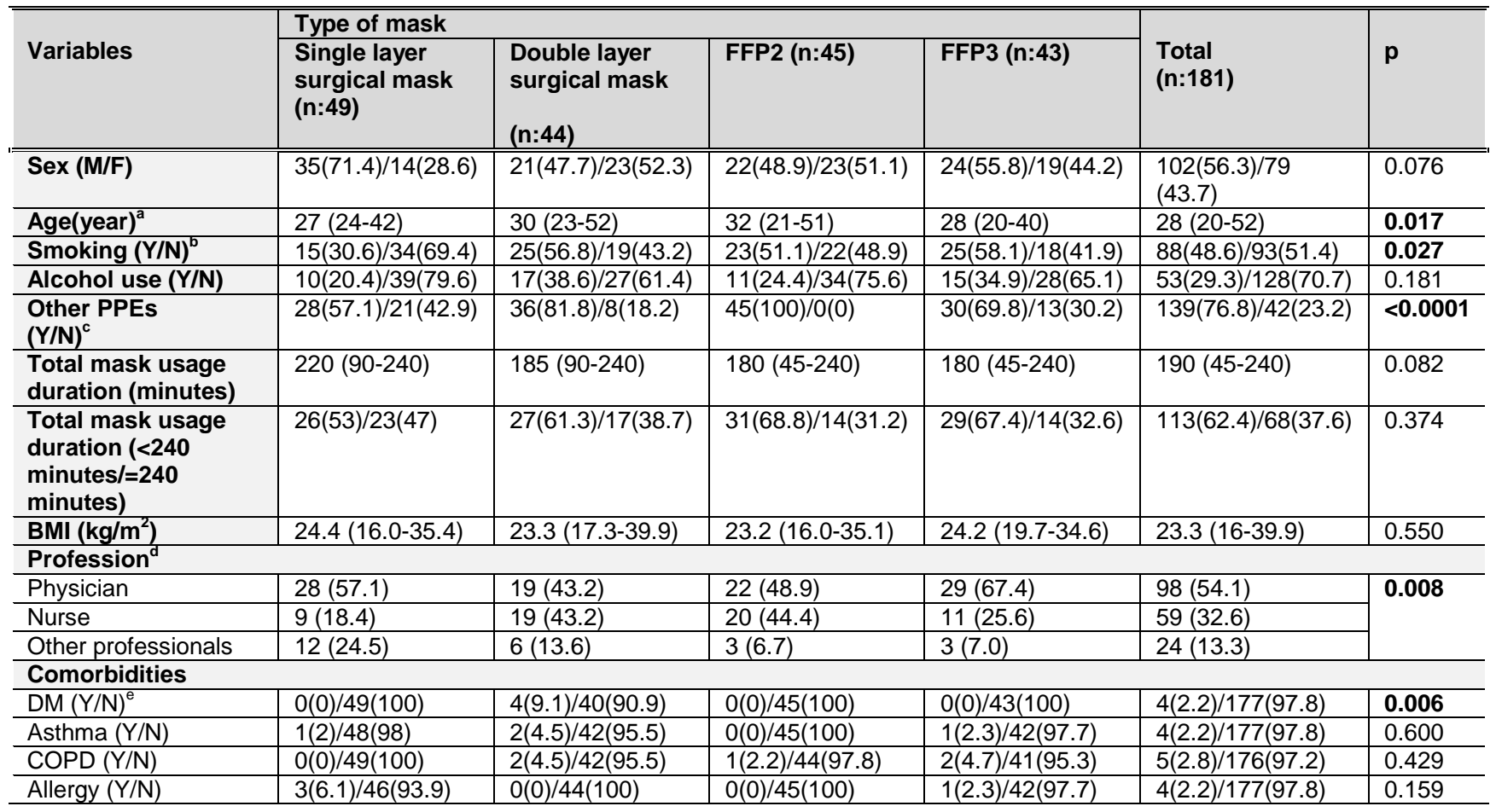

Categorical data are shown as $\mathrm{n}$ (column \%), continuous data are shown as median (min-max). a, Kruskal Wallis test, post hoc pairwise comparisons were performed, and the significance was lost. b, Chi-square test and post hoc Bonferroni correction were performed, there is a difference between surgical mask and FFP3. c, Chi-square test and post hoc Bonferroni correction performed, FFP2 is different from the others. d, Chi-square test and post hoc Bonferroni correction were performed, and the use of surgical masks in nurses is less compared to FFP2. e, Chi-square exact test and post hoc Bonferroni correction were made, the difference disappeared when correction was made.

Table 2. Characteristics of symptoms by type of mask used

\begin{tabular}{|c|c|c|c|c|c|c|}
\hline Variables & $\begin{array}{l}\text { Type of mask } \\
\text { Single layered } \\
\text { surgical } \\
(n: 49)\end{array}$ & $\begin{array}{l}\text { Double } \\
\text { layered } \\
\text { surgical ( } n: 44)\end{array}$ & FFP2 (n:45) & FFP3 (n:43) & $\begin{array}{l}\text { Total } \\
(\mathrm{n}: 181)\end{array}$ & $\mathbf{p}$ \\
\hline \multicolumn{7}{|l|}{ The first symptom that occurs due to mask use } \\
\hline Chest pain & $1(2.0)$ & $1(2.3)$ & $1(2.2)$ & $0(0.0)$ & $3(1.7)$ & \multirow{3}{*}{0.27} \\
\hline Headache & $7(14.3)$ & $3(6.8)$ & $1(2.2)$ & $3(7.0)$ & $14(7.7)$ & \\
\hline Dizziness & $1(2.0)$ & $0(0.0)$ & $0(0.0)$ & $0(0.0)$ & $1(0.6)$ & \\
\hline First symptom/discomfort onset (minutes) & $70(20-200)$ & $50(20-205)$ & $50(15-200)$ & $50815-200)$ & $50(15-205)$ & 0.094 \\
\hline \multicolumn{7}{|c|}{ The main symptom of the removal of the mask ${ }^{\mathrm{a}}$} \\
\hline Shortness of breath & $21(42.9)$ & $16(36.4)$ & $12(26.7)$ & $14(32.6)$ & $63(34.8)$ & \multirow[t]{4}{*}{0.004} \\
\hline Chest pain & $15(30.6)$ & $10(22.7)$ & $20(44.4)$ & $16(37.2)$ & $61(33.7)$ & \\
\hline Headache & $11(22.4)$ & $9(20.5)$ & $2(4.4)$ & $8(18.6)$ & $30(16.6)$ & \\
\hline Dizziness & $1(2.0)$ & $0(0.0)$ & $5(11.1)$ & $0(0.0)$ & $6(3.3)$ & \\
\hline $\begin{array}{l}\text { Duration for symptoms to disappear after } \\
\text { mask removal (minutes) }\end{array}$ & $20(10-30)$ & $15(5-30)$ & $15(5-30)$ & $20(5-30)$ & $15(5-30)$ & 0.424 \\
\hline $\begin{array}{l}\text { Need for treatment for the main symptom } \\
\text { (Y/N) }\end{array}$ & $2 / 47$ & $3 / 41$ & $1 / 44$ & $1 / 42$ & $7 / 174$ & 0.721 \\
\hline
\end{tabular}

Categorical data are shown as $\mathrm{n}$ (column \%), continuous data are shown as median (min-max).

a Chi-square test and post hoc Bonferroni correction were performed, there is a difference in smoking desire between surgical mask and double layer surgical mask. 
Table 3. The relations between the presence of main symptoms related to mask use and demographic characteristics

\begin{tabular}{|c|c|c|c|}
\hline \multirow[b]{2}{*}{ Variables } & \multicolumn{2}{|c|}{ Occurrence of symptoms } & \multirow[b]{2}{*}{$\mathbf{p}$} \\
\hline & No $(n=63)$ & Yes $(n=118)$ & \\
\hline Sex (M/F) & (33(52.4)/30(47.6) & (69(58.5)/49(41.5) & 0.431 \\
\hline Age (year) & $28(23-48)$ & $29(20-52)$ & 0.292 \\
\hline Alcohol use (Y/N) & $18(28.6) / 45(71.4)$ & $35(29.7) / 83(70.3)$ & 0.878 \\
\hline Other PPEs (Y/N) & $48(76.2) / 15(23.8)$ & $91(77.1) / 27(22.9)$ & 0.888 \\
\hline \multicolumn{4}{|l|}{ Profession } \\
\hline Physician & $33(33.7)$ & $65(66.3)$ & \multirow[t]{3}{*}{0.929} \\
\hline Nurse & $21(35.6)$ & $38(64.4)$ & \\
\hline Other professionals & $9(37.5)$ & $15(62.5)$ & \\
\hline \multicolumn{4}{|l|}{ Comorbidities } \\
\hline $\mathrm{DM}(\mathrm{Y} / \mathrm{N})$ & $2(3.2) / 61(96.8)$ & $2(1.7) / 116(98.3)$ & 0.611 \\
\hline
\end{tabular}

Categorical data are shown as $\mathrm{n}($ row \%), continuous data are shown as median (min-max).

\section{DISCUSSION}

One of the main methods of protection from COVID-19 is personal protective masks. The WHO recommends the use of masks for all HCPs, for individuals experiencing any symptoms. individuals awaiting COVID-19 test results, those who have positive results. and those caring for them (14).

In this study, 181 HCPs using face masks were evaluated. The participants' most common symptom was dyspnea. The severity of the first symptom was found to be tolerable at the first hour of use in all mask types. according to the seven-point Likert scale. The duration of symptoms related to the masks was, on average. 70 minutes for the surgical masks and 50 minutes for the other mask types. Although not statistically significant, the duration of mask use was shorter in those using FFP2 and FFP3 masks. Nevertheless, a break after an average of 180 minutes of active patient care for those using FFP2 and FFP3 masks may be suggested. The single- or double-layer surgical masks were better tolerated by the users for 240 minutes.

The presence of symptoms related to mask use did not differ according to sex, age, smoking history, alcohol use, use of protective equipment. BMI, occupation, and the presence of comorbidities $(p>0.05)$. Due to the low prevalence of diabetes and cardiopulmonary disease in our participants, the relationship between a history of comorbidities and symptoms related to mask use could not be evaluated.

In a study conducted in India, $67 \%$ of $423 \mathrm{HCPs}$ preferred N95 masks (equivalent to FFP2), while 33\% preferred surgical masks (15). In another study, 59.2\% of 343 healthcare workers, $91 \%$ of whom were women, preferred to use $\mathrm{N} 95$ masks in the clinic where COVID19 patients were treated, while $40.8 \%$ preferred to use surgical masks (13). In this study, the prevalence of surgical masks use was higher (51\%). This difference might be because of the previous studies were conducted in the early period of the pandemic when the level of protection of face masks was not well-known yet. The permeability of half-face masks and surgical masks worn as one, two, three, and five layers was compared in a study examining the effectiveness of the use of multi-layer surgical masks. Although an increase in mask layers increased filtration, the study did not compare masks with layers to particle respirators such as N95 respirators (16). The Centers for Disease 
Table 4. Presence of symptoms at different times according to mask types

\begin{tabular}{|c|c|c|c|c|c|c|}
\hline & \multicolumn{4}{|c|}{ The type of mask (\%) } & \multirow[b]{2}{*}{$\begin{array}{l}\text { General } \\
\text { (n:181) }\end{array}$} & \multirow[b]{2}{*}{$\mathbf{p}$} \\
\hline & $\begin{array}{l}\text { Surgical } \\
(\mathrm{n}: 49)\end{array}$ & $\begin{array}{l}\text { Double layered } \\
\text { surgical } \\
(\mathrm{n}: 44)\end{array}$ & FFP2 (n:45) & FFP3 (n:43) & & \\
\hline \multicolumn{7}{|c|}{ Shortness of breath } \\
\hline 1. hour $(\mathrm{n}: 181)$ & $3(6.1)^{a}$ & $17(38.6)^{0}$ & $42(93.3)^{c}$ & $37(86.0)^{\mathrm{C}}$ & $99(54.7)$ & $<0.001$ \\
\hline 2. hour (n:177) & $22(44.9)^{\mathrm{a}}$ & $43(97.7)^{b}$ & $42(97.7)^{b}$ & $41(100.0)^{b}$ & $148(83.6)$ & $<0.001$ \\
\hline 3. hour (n:156) & $40(88.9)$ & $40(93.0)$ & $27(84.4)$ & $32(88.9)$ & $139(89.1)$ & 0.728 \\
\hline 4. hour (n:92) & $29(93.5)$ & $20(90.9)$ & $19(95.0)$ & $19(100.0)$ & 87 (94.6) & 0.768 \\
\hline \multicolumn{7}{|l|}{ Chest pain } \\
\hline 1. hour $(\mathrm{n}: 181)$ & $0(0.0)$ & $0(0.0)$ & $0(0.0)$ & $0(0.0)$ & $0(0.0)$ & - \\
\hline 2. hour (n:177) & $1(2.0)$ & $0(0.0)$ & $0(0.0)$ & $2(4.9)$ & $3(1.7)$ & 0.183 \\
\hline 3. hour (n:156) & $4(8.9)$ & $4(9.3)$ & $0(0.0)$ & $4(11.1)$ & $12(7.7)$ & 0.357 \\
\hline 4. hour (n:92) & $5(16.1)$ & $1(4.5)$ & $6(30.0)$ & $3(15.8)$ & $15(16.3)$ & 0.179 \\
\hline \multicolumn{7}{|l|}{ Headache } \\
\hline 1. hour (n:181) & $0(0.0)^{\mathrm{a}}$ & $2(4.5)^{a . b}$ & $7(15.6)^{b}$ & $3(7.0)^{a . b}$ & $12(6.6)$ & 0.018 \\
\hline 2. hour (n:177) & $15(30.6)^{\mathrm{a}}$ & $26(59.1)^{b}$ & $25(58.1)^{b}$ & $24(58.5)^{b}$ & $90(50.8)$ & 0.011 \\
\hline 3. hour (n:156) & $34(75.6)$ & $33(76.7)$ & 18 (56.2) & $27(75.0)$ & $112(71.8)$ & 0.184 \\
\hline 4. hour (n:92) & $28(90.3)$ & $15(68.2)$ & $17(85.0)$ & 17 (89.5) & 77 (83.7) & 0.153 \\
\hline \multicolumn{7}{|l|}{ Dizziness } \\
\hline 1. hour (n:181) & $0(0.0)$ & $2(4.5)$ & $3(6.7)$ & $3(7.0)$ & $8(4.4)$ & 0.314 \\
\hline 2. hour (n:177) & $8(16.3)^{a}$ & $17(38.6)^{a}$ & $8(18.6)^{a}$ & $13(31.7)^{a}$ & $46(26.0)$ & 0.047 \\
\hline 3. hour (n:156) & $34(75.6)$ & $33(76.7)$ & $18(56.2)$ & $27(75.0)$ & $112(71.8)$ & 0.184 \\
\hline 4. hour (n:92) & $19(61.3)$ & $13(59.1)$ & $15(75.0)$ & $12(63.2)$ & $59(64.1)$ & 0.709 \\
\hline \multicolumn{7}{|c|}{ Nausea/vomiting } \\
\hline 1. hour (n:181) & $0(0.0)$ & $0(0.0)$ & $0(0.0)$ & $0(0.0)$ & $0(0.0)$ & - \\
\hline 2. hour (n:177) & $0(0.0)$ & $2(4.5)$ & $0(0.0)$ & $0(0.0)$ & $2(1.1)$ & 0.171 \\
\hline 3. hour (n:156) & $0(0.0)^{\mathrm{a}}$ & $3(7.0)^{a}$ & $0(0.0)^{\mathrm{a}}$ & $0(0.0)^{a}$ & $3(1.9)$ & 0.039 \\
\hline 4. hour (n:92) & $1(3.2)$ & $0(0.0)$ & $3(15.0)$ & $3(15.8)$ & $7(7.6)$ & 0.122 \\
\hline \multicolumn{7}{|l|}{ Blurred vision } \\
\hline 1. hour (n:181) & $0(0.0)$ & $0(0.0)$ & $0(0.0)$ & $0(0.0)$ & $0(0.0)$ & - \\
\hline 2. hour (n:177) & $1(2.0)$ & $0(0.0)$ & $2(4.7)$ & $2(4.9)$ & $5(2.8)$ & 0.480 \\
\hline 3. hour $(\mathrm{n}: 156)$ & $0(0.0)$ & $3(7.0)$ & $0(0.0)$ & $2(5.6)$ & $5(3.2)$ & 0.167 \\
\hline 4. hour (n:92) & $0(0.0)$ & $0(0.0)$ & $2(10.0)$ & $0(0.0)$ & $2(2.2)$ & 0.086 \\
\hline \multicolumn{7}{|l|}{ Palpitation } \\
\hline 1. hour (n:181) & $2(4.1)$ & $1(2.3)$ & $0(0.0)$ & $0(0.0)$ & $3(1.7)$ & 0.565 \\
\hline 2. hour (n:177) & $3(6.1)$ & $4(9.1)$ & $0(0.0)$ & 6 (14.6) & $13(7.3)$ & 0.074 \\
\hline 3. hour (n:156) & $11(24.4)$ & $11(25.6)$ & $5(15.6)$ & $10(27.8)$ & 37 (23.7) & 0.663 \\
\hline 4. hour (n:92) & $6(19.4)$ & $1(4.5)$ & 6 (30.0) & 7 (36.8) & $20(21.7)$ & 0.060 \\
\hline \multicolumn{7}{|l|}{ Tachypnea } \\
\hline 1. hour (n:181) & $2(4.1)$ & $7(15.9)$ & 6 (13.3) & $8(18.6)$ & $23(12.7)$ & 0.168 \\
\hline 2. hour (n:177) & $6(12.2)^{\mathrm{a}}$ & $14(31.8)^{a . b}$ & $27(62.8)^{\mathrm{C}}$ & $24(58.5)^{b . c}$ & $71(40.1)$ & $<0.001$ \\
\hline 3. hour (n:156) & $31(68.9)$ & $27(62.8)$ & $14(43.8)$ & $21(58.3)$ & $93(59.6)$ & 0.161 \\
\hline 4. hour (n:92) & $19(61.3)$ & $14(63.6)$ & $16(80.0)$ & $14(73.7)$ & $63(68.5)$ & 0.484 \\
\hline \multicolumn{7}{|c|}{ A feeling of fainting } \\
\hline 1.hour (n:181) & $0(0.0)$ & $0(0.0)$ & $0(0.0)$ & $0(0.0)$ & $0(0.0)$ & - \\
\hline 2.hour (n:177) & $0(0.0)$ & $0(0.0)$ & $1(2.3)$ & $1(2.4)$ & $2(1.1)$ & 0.360 \\
\hline 3.hour (n:156) & $0(0.0)$ & $0(0.0)$ & $0(0.0)$ & $0(0.0)$ & $0(0.0)$ & - \\
\hline 4.hour (n:92) & $0(0.0)$ & $0(0.0)$ & $1(5.0)$ & $0(0.0)$ & $1(1.1)$ & 0.424 \\
\hline \multicolumn{7}{|c|}{ Increased Anxiety } \\
\hline 1. hour $(\mathrm{n}: 181)$ & $0(0.0)^{\mathrm{a}}$ & $7(15.9)^{b}$ & $3(6.7)^{a . b}$ & $5(11.6)^{a . b}$ & $15(8.3)$ & 0.032 \\
\hline 2. hour (n:177) & $3(6.1)^{a}$ & $3(6.8)^{a}$ & $10(23.3)^{\mathrm{a}}$ & $4(9.8)^{a}$ & $20(11.3)$ & 0.035 \\
\hline 3. hour (n:156) & $25(55.6)$ & $33(76.7)$ & 18 (52.9) & $21(56.8)$ & $97(61.0)$ & 0.100 \\
\hline 4. hour (n:92) & $27(87.1)$ & 17 (77.3) & $18(90.0)$ & 16 (84.2) & $78(84.8)$ & 0.695 \\
\hline
\end{tabular}

Chi-square test and post hoc Bonferroni correction were made, and the differences between the groups are shown in lower case letters. 
Control and Prevention (CDC) suggest that doublelayer masks are effective. However, the use of two surgical masks together is not recommended (17).

In a study by Kumar and Singh (2021), 423 HCPs aged between 21 and 47 years were followed. The most common symptoms after mask use were headache (23\%), dry nose (22\%), dry eyes (19\%), and acne (12\%). Impaired cognition was found in $5 \%$ of the participants (15), In another multicenter study conducted in the USA, the most common symptom was headache, with a rate of $71.4 \%$. Disruption of consciousness occurred in $23.6 \%$ of participants (13). In our study, the two most frequently encountered symptoms in all mask types were dyspnea and headache. The participants rated their symptoms as an average of two points on a seven-point Likert scale measuring the severity of symptoms. The reason why headache was often seen as the first symptom in the above-mentioned studies could be that hourly followups were not included in both studies, and the researchers may have evaluated symptoms due to long-term use. However, our study evaluated the volunteers' early symptoms while they were actively working in the clinic. Therefore, dyspnea was a more common symptom than headache in our study.

The WHO currently does not recommend wearing a mask while working out (18) and acknowledges that wearing a mask during high-intensity physical activities can be difficult (19). The increasing number of COVID19 patients creates a significant workload for HCPs who work on the front line. We can liken this work to light exercise, as it requires a significant amount of extra effort while taking care of patients due to donning a mask and other PPE. Therefore, it is understandable that dyspnea was the first symptom in our participants who were on the move in the EDs.

While there was no headache in the first hours of mask use in the participants who used surgical masks. headache was observed in the participants who wore
FFP2 or FFP3. The frequency of headaches in the first hour of mask use was significantly higher in the participants using FFP2 masks compared to the other mask types. This may be because $\mathrm{CO}_{2}$ accumulates less in single-layer masks. In a study examining the relationship between headache and N95 masks, 34 participants over the age of 18 were instructed to wear N95 masks for one to four hours for surgery and again next day. After using the mask, the participants were evaluated for symptoms and blood gas parameters. In the blood gas evaluations of the participants using N95 masks, respiratory alkalosis and hypercapnia were detected. This was associated with headache, anxiety, tremor, and muscle spasms in the follow-up of the participants (20). Although the finding of dyspnea in our study is not compatible with the literature, it could be related to the hypercapnic state of the participants using masks. In a study of volunteers who exercised with respiratory protective devices. It was also shown that hypercapnia caused dyspnea (21). In another study, headaches that occurred in the participants who donned N95 mask disappeared 30 minutes after mask removal in $14 \%$ of the participants, while it took one hour in $33.8 \%$ of the participants. Moreover, $28 \%$ of the participants needed to use pain relief for their headache (13). The symptoms of our participants were followed up after the mask was removed. The average duration of their complaints was 20 minutes for the surgical and the FFP3 masks and 15 minutes for the double-layer surgical masks and the FFP2 masks. The recovery time in our participants was shorter than in the literature.

The dyspnea and headache we detected in our study. which were also prominent in other studies in the literature, pose an important problem for mask users. Surgical masks trap exhaled $\mathrm{CO}_{2}$ less than particulate masks with valves (22). $\mathrm{CO}_{2}$ retention occurs at a higher rate in particulate masks without exhalation valves. Symptoms caused by hypercapnia and respiratory alkalosis cause a desire to remove masks in 
healthcare workers. This situation means that the PPE is deprived of the mask. Use of systems with ventilation valves that provide $\mathrm{CO}_{2}$ excretion in mask use will ensure that the wearer encounters symptoms less. However, if masks with this feature cannot be supplied, they should take more frequent breaks.

Dyspnea at the first and the second hours was seen significantly less in those using surgical masks and significantly more in those using FFP2 and FFP3 masks compared to the other two mask types. This may be due to less air exchange in the FFP2 and FFP3 masks. The fast-paced environment in the ED may have contributed to this. The reason for the headache that increases in the following hours due to mask use may be due to hypercapnia. In addition, all mask types were not associated with an increase in anxiety in the first hour, but an association was observed in the following hours.

\section{Limitations}

This study has several limitations. First, volunteers with different physiology may have different tolerance capacities for various mask types. Second, volunteers were included in the study with a single mask type of their choice. Different mask experiences of the same volunteers were not tested in this study. Third, when symptoms developed, vital signs and blood gas parameters were not evaluated. Therefore, symptoms and their severity may have differed according to the volunteers' tolerance capacity. Fourth, infection transmission risk between the mask types was not evaluated in this study. Therefore, a recommendation for mask type cannot be made according to this study's results.

\section{CONCLUSION}

In this study, dyspnea and headache were among the most common reasons for the intolerance of masks used by HCPs. The average onset of the first symptoms was 70 minutes in the surgical masks and 50 minutes in the FFP2 and the FFP3 masks. Although no statistical significance was found. The duration of mask use was lower in those who used FFP2 and FFP3 masks. The single- or double-layer surgical masks provided a better of tolerability compared to FFP2 or FFP3 masks. Most symptoms related to mask use can resolve spontaneously without the need for further medical intervention.

Informed Consent: Informed consent was obtained from patients who participated in this study.

Conflict of Interest: The authors declare that they have no conflict of interest.

Financial Disclosure: No funding was taken for this study.

\section{REFERENCES}

1. Huang C, Wang $\mathrm{Y}$, Li $\mathrm{X}$, et al. Clinical features of patients infected with 2019 novel coronavirus in Wuhan, China. Lancet 2020;395:497-506.

2. Center for Systems Science and Engineering at Johns Hopkins University. COVID-19 Dashboard. September 12, 2021. Available at: https://gisanddata.maps.arcgis.com/apps/dashboards/bda75947 40fd40299423467b48e9ecf6. September 12, 2021.

3. Paules $\mathrm{Cl}$, Marston $\mathrm{H}$, Fauci AS. Coronavirus Infections-More Than Just the Common Cold. JAMA 2020;323(8):707-708.

4. Osseiran, N. WHO calls for healthy, safe and decent working conditions for all health workers amidst COVID-19 pandemic. April, 28 2020. Available at: https://www.who.int/news/item/2804-2020-who-calls-for-healthy-safe-and-decent-workingconditions-for-all-health-workers-amidst-covid-19-pandemic. Accessed September 12, 2021.

5. World Health Organization. Rational use of personal protective equipment for coronavirus disease (COVID-19) and considerations during severe shortages. December 23, 2020. Available at: https://www.who.int/publications/i/item/rational-useof-personal-protective-equipment-for-coronavirus-disease-(covid19)-and-considerations-during-severe-shortages. Accessed September 12, 2021.

6. National Institute for Occupational Safety and Health. COVID-19 Information for the Workplace. October 5, 2021. Available at: https://www.cdc.gov/niosh/emres/2019_ncov_default.html. Accessed February 12, 2022.

7. Wizner K, Nasarwanj M, Fisher E, Steege AL, Boiano JM. Exploring respiratory protection practices for prominent hazards in healthcare settings. J Occup Environ Hyg. 2018 Aug;15(8):588-97. 
8. Zhang $\mathrm{X}$, Li H, Shen S, Cai M. Investigation of the flow-field in the upper respiratory system when wearing N95 filtering facepiece respirator. J Occup Environ Hyg. 2016;13(5):372-82.

9. Gillespie, C. Does Wearing a Face Mask Reduce Oxygen-and Can It Increase CO2 Levels? Here's What Experts Say. May 13, 2020. Available at: https://www.health.com/condition/infectiousdiseases/coronavirus/does-wearing-face-mask-increase-co2levels. Accessed September 12, 2021.

10. Johnson, AT, Respirator masks protect health but impact performance: a review. J Biol Eng. 2016;Feb 9;10:4

11. Scarano A, Inchingolo F, Lorusso F. Facial Skin Temperature and Discomfort When Wearing Protective Face Masks: Thermal Infrared Imaging Evaluation and Hands Moving the Mask. Int J Environ Res Public Health. 2020 Jun 27;17(13):4624

12. Siegel JD, Rhinehart E, Jackso M, et al. Guideline for Isolation Precautions: Preventing Transmission of Infectious Agents in Health Care Settings. Am J Infect Control. 2007 Dec; 35(10): S65-S164.

13. Rosner E. Adverse Effects of Prolonged Mask Use among Healthcare Professionals during COVID-19. J Infect Dis Epidemiol 2020;6:130.

14. Coronavirus disease (COVID-19): Masks. January 5, 2022. Available at: https://www.who.int/news-room/questions-andanswers/item/coronavirus-disease-covid-19-masks. Accessed February 24, 2022.

15. Kumar S, Singh A. Prolonged Use of $n 95$ Mask a Boon or Bane to Healthcare Workers During Covid-19 Pandemic. Indian J Otolaryngol Head Neck Surg. 2021;Jan 25:1-4.
16. Derrick JL, Gomersall CD. Protecting healthcare staff from severe acute respiratory syndrome: filtration capacity of multiple surgical masks. J Hosp Infect. 2005 Apr;59(4):365-8

17. Improve How Your Mask Protects You. About COVID-19. April 6, 2021. Available at: https://www.cdc.gov/coronavirus/2019ncov/your-health/effective-masks.html. Accessed February 24, 2022.

18. World Health Organization. Coronavirus Disease (COVID-19) Advice for the Public: Myth Busters. January 19, 2022. Available at. https://www.who.int/emergencies/diseases/novel-coronavirus2019/advice-for-public/myth-busters. Accessed February 24, 2022.

19. Considerations for Wearing Cloth Face Coverings. June 28, 2020 Available at: https://stacks.cdc.gov/view/cdc/90553. Accessed February 24, 2022.

20. Ipek S, Yurttutan S, Gul UU, Dalkiran T, Acıpayam C. Doganer A. Is N95 face mask linked to dizziness and headache? Int Arch Occup Environ Health. 2021 Oct;94(7):1627-36.

21. Smith CL, Whitelaw JL, Davies B. Carbon dioxide rebreathing in respiratory protective devices: influence of speech and work rate in full-face masks. Ergonomics. 2013;56(5):781-90

22. Geiss O. Effect of Wearing Face Masks on the Carbon Dioxide Concentration in the Breathing Zone. Aerosol Air Qual. Res.. 2021;21(2):200403.

Cite as: Duyan M, Ozturan IU, Ozbet MA, et al. Comfort and tolerability of protective face masks used by healthcare professionals during the COVID-19 pandemic. Eskisehir Med J. 2022;3(1):17-26. 